\title{
Eksemplaarinen oppiminen ammattiyhdistyskoulutuksessa
}

\begin{abstract}
Lakkala, Heikki. 1985. Eksemplaarinen oppiminen ammattiyhdistyskoulutuksessa. Aikuiskasvatus 5, 1, 4-10. - Artikkeli kuvaa Oskar Negtin kehittämää eksemplaarisen oppimisen teoriaa ja sen soveltamista ay-liikkeen koulutukseen Saksan liittotasavallassa. Artikkelissa tarkastellaan teorian lähtökohtia, taustaa, sisältöä ja käytännön soveltamisen ongelmia.
\end{abstract}

Oskar Negtin teorialla eksemplaarisesta oppimisesta ja sen soveltamisesta ammattiyhdistyskoulutukseen on perustansa käytännön työväen sivistystyössä. Lähtökohtana on länsisaksalaisen ammattiyhdistyskoulutuksen tilanne 1960-luvun alussa, jolloin Negt toimi ensin Länsi-Saksan ammattiliittojen keskusliiton koulutuslaitoksen johtajana ja työskenteli sen jälkeen metallityöväenliiton koulutusosastolla. (Negt 1976, 367.) Tällöin hän oli mukana kehittämässä metaililiitolle uutta koulutuskonseptiota, jonka perusajatuksena oli eksemplaarinen oppiminen. Vähitellen tämä konseptio saaputti merkitystä käytännön ammattiyhdistyskoulutuksessa ja sitä on sovellettu käytäntöön varsin laajasti. (Negt, haastattelu 1.) "Sosiologinen mielikuvitus ja eksemplaarinen oppiminen" -teoksessa hahmoteltu työväen sivitystyön teoria pohjautuu paljolti tuolloin saatuihin kokemuksiin ja on osin niiden teoreettista tarkastelua (Negt $1971,12$.$) .$

Negt ei pyrikään esittämään teoriaansa eksemplaarisesta oppimisesta yleisenä kasvatusteoriana, vaan hän rajaa sen hyvin selkeästi koskemaan työväen sivistystyötä. Hänen mielestään mitään tietokriittisten, metodologisten ja didaktisten pohdintojen tasoa ei pidä pitää erillään koulutussisältöjen määrittelystä ja kohderyhmän problematiikasta. (Negt 1971, 11-12.)

Seuraavassa hahmotellaan ensin sitä ammattiyhdistyskoulutuksen tilannetta, johon eksemplaariseen oppimiseen perustuvalla koulutuskonseptiolla tavallaan reagoitiin. Sitten selvitellään, mitä Negt eksemplaarisella oppimisella tarkoittaa ja mihin seikkoihin siinä erityisesti kiinnitetään huomiota. Lopuksi kommentoin muuatta Negtin ajatuksiin kohdistettua kritiikkiä.

\section{Eksemplaarisen oppimiskäsityksen taustaa}

Eksemplaarista oppimisen konseptiota ruvettiin kehittämään ammattiyhdistyskoulutuksen lähtökohdaksi tilanteessa, jossa ammattiyhdistyskoulutus oli pääosin toimitsijakoulutusta ${ }^{1}$. Sen lisäksi järjestettiin siitä erillään olevaa poliittisesti suuntautunutta mielipidekoulutusta. Toimitsijakoulutuksessa sen sijaan pyrittiin antamaan toimitsijoille heidän käytännön työssä tarvitsemiaan tietoja sen kaltaisissa kysymyksissä kuin työoikeus, sosiaalilainsäädäntö, työehtosopimusten tulkinta ja yritystalous. Samaten käsiteltiin kansantaloustiedettä, teollisuussosiologiaa, rahapolitiikkaa. Tavoitteena oli teknis-käytännöllisen tiedon jakaminen. Kouluttajina käytettiin asiantuntijoita, jotka tulivat akateemisesta maailmasta tai esimerkiksi oikeuslaitoksen piiristä ja joilla ei niin muodoin ollut yhteyttä ammattiyhdistysliikkeen tavoitteenasetteluun ja ajattelutapoihin. Näin ei myöskään ajatus yhteiskunnallisen vapautumisen edesauttamisesta, emansipaatiovaatimus, tullut koulutuksessa esille. (Negt 1976, 359, 369; haastattelu 2.)

Koulutustoiminnan lähtöoletuksena oli, että liikkeen jäsenet saavat poliittisen kasvatuksensa ja muodostavat yhteiskunnalliset näkemyksensä ensi sijassa välittömässä järjestötoiminnassa. Koulutustoiminnan päätehtävä oli huolehtia siitä, että toimitsijat toimivat, ja siihen tähtäävä koulutus pidettiin radikaalisti erillään työläisten elinolojen muuttamiseen

1) Toimitsijoilla ei saksalaisessa kielenkäytössä tarkoiteta ainoastaan järjestöjen palkallisia toimihenkilöitä, vaan myös tärkeiden luottamustehtävien haltijoita, kuten luottamusmiehiä tai yritysneuvostojen jäseniä. 
suuntautuneesta emansipaatiotiedosta. (Negt 1976, 359.)

Negt asettaa ammattiyhdistyskoulutuksen päätavoitteeksi yhteiskunnallisen tietoisuuden kehittämisen. Tällöin on tärkeää, että koulutuksessa lähdetään liikkeelle osanottajien itseymmärryksestä ja todellisuudenkäsityksestä (Negt 1976, 358.). Tavoitteena on, että koulutukseen osallistuvat työläiset oppivat tulkitsemaan omia konfliktikokemuksiaan yhteiskunnallisina konflikteina ja ymmärtämään oman asemansa yhteiskunnan rakenteiden ja ristiriitojen valossa, eikä niinkään, että he omaksuisivat mahdollisimman suuren määrän erillistietoja. (Negt, haastattelu 2.)

Koska tavoitteena on aktivoida työläiset poliittiseen toimintaan ja edesauttaa heitä orientoitumaan yhteiskunnallisiin asioihin, on koulutuksen kehitettävä ennen muuta heidän kykyään valikoida, työstää ja arvioida informaatiota. Koulutus kohdistui ennen muuta koulutusvastaaviin, joiden tehtävänä oli omilla työpaikoillaan itse järjestää koulutusta muulle jäsenistölle. (Negt 1976, 362-3; haastattelu 2.).

Kyky käsitellä tietoa kriittisesti ei kuitenkaan ole joukko abstrakteja sääntöjä, joita voi soveltaa haluttuun kohteeseen. Kriittistä tiedonkäsittelykykyä ei voi opettaa sellaisenaan, irrallisena, vaan se voi kehittyä vain jonkin sisällöllisen aihealueen käsittelyn yhteydessä. (Negt 1976, 362-3.)

Näistä tavoitteista seuraa, että eksemplaarisen oppimisen kannalta on tärkeää analysoida työläisten elämänpiiriin liittyviä konfliktialueita, heidän oppimismotivaatioon ja -esteisiinsä liittyviä tekijöitä sekä heidän itseymmärrystään ja käsityksiään todellisuudesta (Negt 1971, 21.).

\section{Mitä eksemplaarisella oppimisella tarkoitetaan?}

Eksemplaarinen oppiminen voidaan ehkä osuvimmin suomentaa esimerkistä lähteväksi oppimiseksi. Siinä esimerkki tai yksittäinen tapaus on lähtökohta - ja vain lähtökohta josta edetään selvittelemään niitä yleisiä suhteita ja rakenteita, joita tapaus tai esimerkki ilmentää. Negtin konseptiossa nämä lähtökohtaesimerkit ovat nimenomaan konfliktikokemuksia, osallistujien omia tai heidän elämänpiiriään läheisesti koskettavia konfliktikokemuksia.

Konfliktikokemukset ovat tavallaan oppimisprosessin motivaatioperusta. Tätä voisi ehkä verrata kognitiivisen oppimisteorian aja- tukseen kognitiivisesta dissonanssista, tiedollisesta ristiriidasta: oppiminen lähtee siitä, että koetaan tiedollinen ristiriita, joka motivoi oppimaan. Konfliktikokemuksilla on sama funktio kuin tiedollisella ristiriidalla.

Kun Negt puhuu oppimisen nivomisesta kokemuksiin niin tällöin hän tarkoittaa nimenomaan kollektiivisia, yhteiskunnallisia kokemuksia, tässä tapauksessa työläisille yhteisiä kokemuksia, joiden kautta he kokevat yhteiskunnalliset suhteet ja prosessit omassa arkitodellisuudessaan. Kyse ei siis ole yksittäisten ihmisten individuaalisista ja satunnaisista elämyksistä. (Negt 1976, 372-3.)

Eksemplaarisen oppimisen suomentaminen esimerkkioppimiseksi saattaisi viedä ajatukset harhaan sikäli, että eksemplaarisen oppimisen ajatus ei suinkaan tyhjentävästi palaudu sanaan esimerkki. Negt itse vetää rajaa niin sanottuun tapausmenetelmään, jolle on ominaista se, että siinä tapausta käsitellään esimerkkinä useista muista vastaavanlaisista tapauksista. Tapausmenetelmässä esimerkki edustaa vain muita vástaavanlaisia tapauksia, eikä sen avulla pyritä valottamaan mitään yksittäisten tapausten takana olevia rakenteita ja suhteita (Negt 1971, 31.). Tapausmenetelmän ongelmana on se, että sitä käytettäessä yhteiskunta esitettäisiin pelkkien tapausten ja tosiasioiden universumina (em.). Tavoitteena on kuitenkin selvittää yhteiskunnan rakenteita ja siinä vallitsevia suhteita.

Eksemplaarisuuden käsitettä määritellessään Negt uudelleentulkitsee sosiologiselta kannalta Martin Wagenscheinin lähinnä fysiikan opettamista koskevien pohdintojen yhteydessä esittämää ajatusta, että yksittäinen tai eksemplaarinen on kokonaisuuden peili. Eksemplaarisuuden ajatuksen järkevä ydin saadaan Negtin mukaan esiin tulkittaessa tätä siten, että "kokonaisuudella" tarkoitetaan työnjaollisesti organisoitua yhteiskunnan tuotanto- ja uusintamisprosessin kokonaisuutta ja "yksittäisellä" yhteiskunnan, luokan ja yksilön elämän kannalta relevantteja sosiologisia asiantiloja. (Negt 1971, 26-7.)

Eksemplaarisessa oppimisessa on kyse kasvattamisesta sosiologiseen ajattelutapaan, jolla Negt tarkoittaa samaa kuin C. Wright Mills sosiologisella mielikuvituksella (Negt 1971, 278.). Se on "'kyvykkyyttä siirtyä näkökulmasta toiseen - poliittisesta psykologiseen, yksittäisen perheen tutkimisesta kansakuntien tulo- ja menoarvioiden vertailevaan arviointiin (...) ja nähdä niiden väliset yhteydet"' (Mills, 11.). 
Sosiologinen mielikuvitus tekee mahdolliseksi ymmärtää laajoja historiallisia ilmiöitä siltä kannalta, mitä ne merkitsevät ihmisen elämänkululle. Se auttaa etsimään yhteiskunnan rakennetta lähtien liikkeelle ihmisten jokapäiväisistä kokemuksista ja paikallistamaan ihmisten henkilökohtaiset huolet yleisiksi ongelmiksi. Sosiologisen mielikuvituksen ideana on, että yksilö voi ymmärtää omia kokemuksiaan ja arvioida omaa kohtaloaan vain sijoittamalla itsensä aikakauteensa. Näin on mahdollista ymmärtää elämänhistorian ja historian keskinäisiä suhteita. Tähän pystyäkseen ihmiset eivät tarvitse ainoastaan tietoa vaan myös ymmärrystä, joka auttaa heitä käyttämään tietoa, sillä tänä tosiasioiden aikakautena informaatio usein hallitsee ihmisen huomiokykyä ja hukuttaa allensa hänen kykynsä käsitellä tietoa. (Mills, 8-10.)

Eksemplaarisen oppimisen tarkoituksena on siis opettaa ihmiset tajuamaan oman elämänpiirinsä keskeiset konfliktit sekä oma asemansa ja tilanteensa yhteiskunnan rakenteen, yhteiskunnallisten suhteiden ja konfliktien valossa. Samalla pyritään toiselta puolen selvittämään yhteiskunnan rakennetta ja konflikteja työläisten omien tai heidän elämäänsä läheisesti koskettavien konfliktikokemusten kautta, jolloin nämä kokonaisyhteiskunnalliset seikat eivät jää ihmisten elämäntodellisuuden kannalta irrallisiksi vaan ne tajutaan sitä olennaisesti muovaaviksi tekijöiksi.

Kun yhteiskunnallisia suhteita selvitetään lähtien liikkeelle omista kokemuksista ja palauttamalla yleiset yhteydet yhä uudelleen kokemuksiin, niin tällöin yhteiskunnassa vallitsevat konfliktiasetelmat omaksutaan omassa päässä, omatoimisella tutkimisella (Negt, haastattelu 2.). Tällä tavoin kehittyy myös kyky valikoida, työstää ja arvioida informaatiota ja tulkita uusia tilanteita.

Eksemplaarisen oppimisen kannalta on tärkeää muokata oppiaines siten, ettei jäädä tieteenalojen välisen työnjaon vangiksi, vaan ylitetään niiden rajat, jäsennetään ja muokataan niiden kasaamaa tietoa sellaiseen muotoon, että se toisaalta on osanottajien tajuttavissa ja toisaalta kykenee tuomaan esiin yleisiä yhteiskunnallisia yhteyksiä poliittiseen toimintaan motivoivalla tavalla. Usein formalisoidulla ja tiiviillä tieteellisellä kielellä ilmaistu tieto on muutettava sellaiseen muotoon, joka vastaa koulutettavan näkökulmaa. Tällä asialla on myös tärkeä poliittinen ulottuvuutensa. Monimutkaisen - esimerkiksi luonnontieteellisen, taloudellisen tai sotilaallisen - informaation pelkistäminen olennaisiksi, vaihtoehtojen muotoon saatetuiksi kannoiksi on seikka, jon$\mathrm{ka}$ onnistumisesta viime kädessä riippuu mahdollisuus demokraattisesti kontrolloida hallinnollisia ja byrokraattisia päätöksiä. (Negt 1971, 25 ja 29.)

\section{Lähtökohtana konfliktit}

Kokemukset, joista eksemplaarisessa oppimisessa lähdetään, ovat konfliktikokemuksia, joiden kautta yhteiskuntarakenteen ristiriidat ilmenevät työläisten työläisenä olon jäsentäjinä. Ei kuitenkaan riitä, että tyydyttäisiin tulkitsemaan vain institutionaalisia konflikteja, jotka koskevat suoritusvaatimuksia, työn järjestämistä, sopeutumista teknisiin muutoksiin tai erimielisyyksiä esimiesten ja työnantajan kanssa. Näitä on toki välttämätöntä käsitellä, mutta se ei riitä. Työläisten konfliktikokemukset eivät ole objektiivisten konfliktien puhdasta heijastumista subjektiiviselle tasolle, eivätkä objektiivisten konfliktien tulkinnat ole vain reagoimista elämänolosuhteiden huononnuksiin. Siihen, miten kukin yksittäinen konflikti tulkitaan, miten sen merkitys ilmaistaan ja miten se liitetään työläisen aiempien kokemusten yhteyteen, vaikuttaa se, millä tavoin työläisillä on tapana mieltää asioita, millaista on heidän käyttämänsä kieli, millaisia heidän ajattelutapansa ja heille tyypilliset persoonallisuuden piirteet. Konfliktiorientoituneessa työväen sivistystyössä on siksi kyettävä nivomaan yhteen kolme tasoa, joiden kautta konfliktit vasta välittyvät tietoisuuden rakentamisen mahdolliseksi lähtökohdaksi ja sisällöiksi. (Negt 1971, 42-44.)

Ensimmäisenä tasona ovat julkilausutut intressit, käsitykset ja yhteiskuntakuvat. Toisen tason muodostavat psyykkiset ja kognitiiviset vieraantumismekanismit, jotka ovat ominaisia joko koko yhteiskunnalle tai tietylle yhteiskuntaluokalle. Tällaisia ovat esimerkiksi koko yhteiskunnalle ominainen piirre käsitellä asioiden sijasta henkilöitä tai työväenluokan kielenkäyttöön liittyvät luokkaspesifiset piirteet. Se, ettei ole perillä omasta vieraantuneisuudestaan, on omiaan synnyttämään lohduttoman käsityksen omasta tilanteestaan. Omasta vieraantumisesta tietoiseksi tuleminen on edellytys sille, että työläisten tietoisuus omasta itsestään lisääntyy ja tarve poliittiseen vapautumiseen syntyy. Kolmas taso ovat työläisten taloudelliset ja sosiaaliset elinolosuhteet. Negt kiinnittää huomionsa kahteen ensimmäiseen tasoon. (Negt 1971, 43-45.) 
Konflikteihin, olosuhteiden muutoksiin ja valtasuhteisiin reagoiminen on aina kiinteä osa jatkuvaa reaktiota koko työläisenä olemiseen, joka on enemmän ja jotain muuta kuin yksittäisten konfliktien summa. Työläisenä olemisen käsitteellä Negt viittaa ranskalaiseen käsitteeseen "condition ouvrière", jota hän pitää vaikeasti käännettävänä. Se on kuitenkin hänen mielestään osuva sikäli, että se viittaa kaikkiin kolmeen edellä kuvattuun tasoon, eikä rajoitu väitteeseen vain yhteiskunnallisten intressien ja tietoisuuden muotojen kausaalisuhteesta. Siinä otetaan huomioon se, että työläinen käsittelee kohtaamiaan konflikteja ja jännitteitä myös psyykkisellä ja henkisellä tasolla. Tosin siihen, millä tavoin tämä tapahtuu, vaikuttavat monet luonteeltaan yhteiskunnalliset seikat. (Negt 1971, 45.)

Vaikka lähdetäänkin liikkeelle työpaikan konflikteista, ei näkökulmaa suinkaan haluta rajoittaa tälle tasolle, sillä luokkakonfliktit ovat aina kokonaisyhteiskunnallisia konflikteja. Teollisuustyöpaikka on lähtökohtana siksi, että työlaisten siellä saamat työläisenä olemiseen liittyvät primaarikokemukset ovat vaikeimpia verhota. (Negt 1971, 46.)

Konfliktikokemukset ovat sidoksissa ihmisen psyykkisiin mekanismeihin sikäli, että kokemukset työläisenä olon lohduttomuudesta ja työn yhteiskunnallisen mielekkyyden häviämisestä saavat aikaan torjuntamekanismeja. Sitä, ettei todellisia yhteiskunnallisia tarpeita voida tyydyttää eikä työn tuotteiden käyttöön ja työolosuhteiden järjestelyyn päästä yhdessä vaikuttamaan, kompensoidaan korvaavilla tarpeentyydytys- ja toimintatavoilla. Vieraantumisen kompensoinnin muodot määrittelee vallitseva yhteiskunta. Suuntautuminen kulutukseen ja yksityisyyteen ovat tällaisia kompensoivia reaktioita työläisenä olemiseen, ristiriitojen ratkaisun henkilökohtaisia muotoja. Kun ollaan vieraantuneita eli kun työhön ja sen tuotteisiin ei voi samaistua, ei pidetä niitä ominaan, niin silloin työstä saatu maksu on ainoa siitä saatava vastike. Palkalla on näin ollen myös se funktio, että sen avulla aikaansaadaan perusta korviketyydytysten saamiselle. (Negt 1971, 49-54.)

Työläisten intressejä ja yhteiskuntakuvaa määrittää Negtin mukaan seuraava ristiriita: työläinen ei enää halua olla työläinen muttei kuitenkaan pääse eroon tunteesta, että hänen on aina pysyttävä työläisenä. Tästä ristiriidasta käsin ammattiyhdistyskoulutuksessa pitäisi lähteä selvittämään sitä, että konfliktien rat- kaiseminen korvaavan tarpeentyydytyksen tasolla on näennäistä. Heidät on saatava paremmin tajuamaan vallitseva eriarvoisuus. Työläisten tekeminen selvemmin tietoisiksi eriarvoisuudesta selvittämällä heitä koskevia konflikteja ei ole tietoisuuden tuomista ulkoapäin ihmisille, joilla ei jo itsellään olisi edellytyksiä tällaisen tietoisuuden rakentamiseen. Eriarvoisuuden tunne on tosiasiassa varsin keskeinen työläisten tietoisuuden tekijä. (Negt, 1971, 55-56.) Ammattiyhdistysliikkeessä mukana olevilla ihmisillä on yleensä jonkinlainen joskaan ei aina kovin selvä - käsitys siitä, mitä eriarvoisuus ja epäoikeudenmukaisuus merkitsevät. Ihmisillä on olemassa toiveita ja käsityksiä siitä, miten asioiden pitäisi olla. Koulutuksen tehtävänä on tehdä näistä käsityksistä selkeämpiä ja tiedollisesti perusteltuja, saada niiden pohjalta aikaan ihmisissä kognitiivista kehitystä ja toimintavaatimuksia.Kaikkea tietoisuuden rakentamiselle tarpeellista ei tietenkään voida saada esiin ihmisten kokemuksista, mutta sitä voidaan käsitellä kokemusten yhteydessä. (Negt, haastattelu 2.)

Myöhemmin Negt on puhunut ammattiyhdistysliikkeen poliittisen mandaatin laajentamisesta. Sillä hän tarkoittaa, ettei ammattiyhdistysliikkeen pidä rajoittaa toimintaansa vain työpaikoille, vaan sen lisäksi asuinalueista ja kaupunginosista on tehtävä toinen ihmisten organisoinnin ympäristö. Tämä on tärkeää, koska tokikaan kaikki ihmisten elämän kannalta keskeiset kokemukset eivät rajoitu työpaikalle, vaan uutta konfliktipotentiaalia on muuallakin. Asuinympäristössään ihmiset joutuvat vastatusten elinympäristöä koskevien ristiriitojen ja konfliktien kanssa. Työttömyys ja sen uhka on toinen yhä keskeisemmäksi tuleva ristiriitojen ja konfliktien lähde, jonka suuntaan mandaattia pitäisi myös laajentaa. (Negt 1984, 131-140 ja 154-164; haastattelu 1.) Vastaavalla tavalla voidaan konfliktiorientoituneessa koulutuksessa laajentaa käsitystä koulutuksen kannalta relevanteista konfliktikokemuksista.

\section{Kielelliset erityisongelmat}

Kun koulutettavia pidetään oppimisprosessin itsenäisinä subjekteina on tärkeää tarkastella heidän ajattelunsa ja toimintansa kielellisiä perusrakenteita. Ne muodostavat tietyt formaaliset edellytykset heidän tavalleen ymmärtää oma itsensä ja todellisuutensa. Kieli säätelee persoonallisuuden rakentumista samoin kuin se säätelee tietylle yhteiskuntaluokalle 
tyypillisiä kokemusten ja käsitysten organisoinnin muotoja: poliittisia katsomuksia, yhteiskuntakuvaa sekä intressien ja tarpeiden tulkintaa. (Negt 1971, 59.)

Tällaisia ajattelun ja toiminnan kielellisiä perusrakenteita ovat $\mathrm{mm}$. stereotypiat. $\mathrm{Ne}$ edustavat usein kollektiivisia, tietylle ihmisryhmälle yhteisiä kokemuksia, minkä vuoksi tähän ihmisryhmään kuuluvien on helppo pitää niitä ominaan. Stereotypiat vaikuttavat tiedon valikoimiseen ja tapaan hahmottaa todellisuutta. Negt puhuu sosiaalisesta topiikasta, kaikkien työläisten enemmässä tai vähemmässä määrin käyttämien ja ymmärtämien ajatusja ilmaisujärjestelmien kokonaisuudesta. Suurin osa informaation käsittelystä - etenkin välittömän kokemuksen ulottumattomissa olevien asioiden, kuten monimutkaisten poliittisten ja taloudellisten tapahtumainkulkujen tajuaminen - on tällaisten ajatus- ja ilmaisujärjestelmien välittämää. $\mathrm{Ne}$ palvelevat yksilön yhteiskunnallista orientoitumista sikäli, kuin ne ilmaisevat hänen ryhmänsä historiallista kokemusta ja elinolosuhteita. Eri sosiaalisilla ryhmillä saattaa siksi olla joissain suhteissa hyvinkin erilaisia ajatus- ja ilmaisujärjestelmiä. Esimerkiksi jonkin suuryrityksen toimihenkilöillä on jo ratkaisevasti erilainen ajattelu- ja ilmaisujärjestelmä kuin saman tehtaan työläisillä. Tämän vuoksi koulutusta on tarpeen eriyttää, eikä koulutustoiminnassa voida lähteä niputtamaan työläisiä, toimihenkilöitä ja virkamiehiä yhdeksi palkkatyöläisten ryhmäksi, vaikka tämä jossain toisessa katsannossa olisikin perusteltua. Näiden ryhmien erilaiset ajattelu- ja ilmaisujärjestelmät edellyttävät koulutuksen eriyttämistä. (Negt 1971, 62-64.) Eri ryhmillä on myöskin erilaiset konfliktikokemukset ja yhteinen kokemuspohja on liian kapea, jotta asioita voitaisiin käsitellä samoista lähtökohdista. Erilaisten, omalle ryhmälle ominaisten ongelmien ja kokemusten olemassaolon vuoksi on myös perusteltua järjestää omia koulutustilaisuuksia esim. naisille. (Negt, haastattelut.)

Koulutuksessa pitäisi tietoisesti käsitellä tällaisten tulkintamallien sekä yksilöiden oman sosiaalisen itseymmärryksen ja muuttuneen todellisuuden välisiä ristiriitaisuuksia. On kuitenkin väärin suinpäin mitätöidä tällaiset tulkintamallit ja pyrkiä osoittamaan ne ennakkoluuloiksi, ideologisiksi kivettymiksi tai toiveajatteluksi viittaamalla niiden kanssa ristiriidassa oleviin yksittäisiin tosiasioihin. Tulkintamallien ristiriitaisuuksien tarkastelun yhtey- dessä on samalla pyrittävä kaivamaan esiin niiden rationaalinen ydin, johon asioiden käsittelyssä voidaan tukeutua. (Negt 1971, 62-67.) Työläisille yhteisissä tulkintamalleissa on usein löydettävissä - vaikkakaan ei aina kovin eksplikoituna - emansipaatiopyrkimyksiin liittyviä yhteiskuntakriittisiä näkökulmia. Sitäpaitsi, jos nämä tulkintamallit vain mitätöitäisiin, niin silloin työläisiltä otettaisiin pois heidän keskeinen sosiaalisen orientoitumisen ja informaation käsittelyn välineensä (Negt 1971, 67.).

Stereotypioilla ja tulkintamalleilla on vielä sekin merkitys, että ne kompensoivat niitä puutteellisuuksia, joita työläisten käyttämään kieleen sisältyy. Tässä yhteydessä Negt cttaa käyttöön Basil Bernsteinin kerrostumatyypillisten kielellisten rakenteiden muodostumista koskevassa tutkimuksessa tekemän erottelun formaaliseen ja julkiseen (öffentlich) kieleen. Formaalinen kieli on perusrakenteeltaan hallitsevien kerrosten, koulujärjestelmän ja tieteen kieltä. Sillä voidaan täsmällisesti ja erottelukykyisesti puhua suhteista, rakenteista ja prosesseista.

Työläiset sen sijaan käyttävät pääasiallisesti julkista kieltä, jonka käsitteenmuodostusta, sananvalintaa ja lauserakennetta luonnehtii loogisen kompleksisuuden ja yksilöllisten tunteiden objektivoinnin puute. Stereotypioiden kaltaiset tulkintamallit auttavat muotoilemaan ja ilmaisemaan mielipiteitä ja käsityksiä, jotka toimivat sosiaalisen kommunikaation vahvistajina ja laajentajina. Sen sijaan sitä, mitä jotkut asiat yksilölle merkitsevät (Negtin sanoin individuaalisesti tarkoitettuja merkityksiä), ei hahmoteta kielellisesti eikä siten myöskään käsitteellisesti. Kuitenkin juuri tällaisissa merkityksissä saattavat usein tiivistyä yksilön kannalta ratkaisevat yhteiskunnalliset ja henkilökohtaiset konfliktikokemukset. Tämä puute vahvistaa kielellisen kommunikaation tasolla niiden ristiriitojen peittymistä, jotka ovat osa työläisenä olemisen kokonaisuutta. (Negt 1971, 78-80.)

Stereotypiat, yhteiset tulkintamallit ovat koulutuksen näkökulmasta tärkeitä siksi, että niiden avulla tasoitetaan näitä kielellisiä puutteita. Niiden avulla maksimoidaan keskinäistä solidaarisuutta, sidotaan tunteet yhteiskunnallisiin puhetapoihin ja etiketteihin, perinteisiin symboleihin ja ilmaisutapoihin. Ammattiyhdistyskoulutuksen, jonka tavoitteena on tietoisuuden rakentaminen ja poliittiseen toimintaan kasvattaminen, täytyy pyrkiä saamaan 
esiin ja tiedostetuksi sekä mainitut kielellisesti ja käsitteellisesti käsittämättä ja erittelemättä jääneet kokemussisällöt että työväestön perinteisiin symboleihin ja ajatusmaailmaan sisältyvät yhteiskuntakritiikin ainekset. Näitä molempia pitää käsitellä formaalisen kielen ja kokemustieteellisen tiedon välinein. (Negt 1971, 79-80.)

Tämä edellyttää yhteiskuntatieteellisen tiedon muokkaamista niin, ettei sitä esitetä formaalis-analyyttisessä ja teknologisessa muodossa vaan se suhteutetaan yhteiskunnalliseen emansipaatioprosessiin. Negtin katsannossa tämä tarkoittaa yhteiskuntatieteellisen tiedon tulkintaa kriittisen yhteiskuntateorian yhteydessä. Tämä merkitsee opetustapahtuman kannalta sitä, että koko ajan rakennetaan siltaa formaalisen kielen ja osallistujien käyttämän kielen välille, yhteiskunnan tieteellisen ja teoreettisen erittelyn ja yhteiskunnan ristiriitojen ilmenemismuotojen työläisten yhteisestä kokemuksesta lähtevän tulkinnan välille. Tämä edellyttää kääntämistä yhdestä ajatus- ja ilmaisujärjestelmästä toiseen, eikä osallistujien pidä olettaa kykenevän tähän ilman muuta omin avuin. Tämä kääntäminen on osa informaation ja opetussisällön muokkaamisen ongelmaa. Mikäli siinä epäonnistutaan, jää oppiminen hajanaisen ja huonosti ymmärretyn informaation mekaaniseksi opetteluksi. Konkreettinen, asenteita ja tietoisuutta yhtälailla muuttava koulutus edellyttää välitystä formaalisen ja julkisen kielen välillä sekä tieteellisen tiedon ja työläisten käytännön tietoisuuteen sisältyvien vapautumispyrkimysten välillä. Tämä on otettava huomioon jo oppiainesta muokattaessa. (Negt 1971, 80-82.)

\section{Esimerkkiaiheena tekniikka}

Negt ottaa esimerkeiksi eksemplaaristen periaatteiden soveltamisesta oppiaineksen uudelleenjärjestämisestä oikeuden ja tekniikan aihealueet. (Negt 1971, 96-118.) Ne ovat tärkeitä alueita sekä yhteiskuntasuhteiden laadullisten muutosten että yhteiskunnan perustavien ristiriitojen peittämisen kannalta. Teknisiä tuotantovoimia sekä sitä, miten luontoa ja inhimillisiä voimavaroja käytetään, ohjaa partikulaarinen rationaalisuus eli joidenkin osittaisetujen kannalta määritelty järkevyys. Sen näkökulmasta vallitseva yhteiskunta voi näyttää periaatteessa järkevästi organisoidulta ja yhteiskunnan laadullinen muuttaminen turhalta tai jopa vahingolliselta. Koulutuksessa täytyy sen vuoksi tuoda esiin tekniikan ja sen käyttötavan rajoittunut luonne ja muutettavuus analysoimalla sitä yhteiskunnan perustavista ristiriidoista käsin. (Negt 1971, 98.)

Jos rajoitutaan automaation teknisesti spesifiin käsittelyyn ja vain sen avaaminen teknisten mahdollisuuksien tarkasteluun, niin tällöin koulutuksessa vain vahvistetaan kuvitelmaa tekniikan ja sen kehityksen luonnonvoimaisuudesta, eikä tekniikkaa kyettäisi käsittämään yhteiskunnan yhden erityisorganisaation osana. Tekniikan merkitys ei kuitenkaan ole vain tekninen vaan myös sosiologinen - sitä enemmän mitä enemmän tekniikka vapauttaa ihmistä työstä. (Negt 1971, 113.)

Tekniikan yhteiskunnallinen problematiikka täyttää ne kriteerit, jotka Negt asettaa eksemplaarisen opetuksen kannalta mielekkäälle teemalle: se on lähellä yksilökohtaisia intressejä; se koskettaa sellaisia työläisten tietoisuuden elementtejä, jotka koskevat yleisempiä yhteiskunnallisia yhteyksiä ja ylittävät sisällöllisesti välittömät intressit; kolmanneksi sillä on merkitystä työläisten emansipaation kannalta. (Negt 1971, 97.)

Viimeisen kriteerin kannalta teknisten tuotantovoimien tason selvittäminen auttaa määrittelemään ihmisten reaalisen tarpeidentyydytyksen objektiiviset mahdollisuudet. (Negt 1971, 114). Näin saadaan konkretisoitua historiallisesti perusteltu mittapuu olemassaolevien olojen kritiikille (em.):mitä tyydyttämättömiä tarpeita olisi mahdollista tyydyttää, minkä tarpeiden tyydyttämistä nykyinen tuotantovoimien taso tai niiden käyttösuunta estävät tai jopa uhkaavat. Toisaalta teknisen edistyksen käsitteeseen liittyy työläisten ajatusmaailmassa oman työpaikan tilanteen ylittäviä näkemyksiä esimerkiksi sodasta, työmarkkinoiden tilanteesta tai työttömyydestä.

Kolmanneksi tekniikka on tärkeä välitystaso välittömien intressien ja kokonaisyhteiskunnallisten ilmiöiden välillä. Sen yhteydessä tulevat esiin erilaiset intressit yrityksen tasolla ja toisaalta kokonaisyhteiskunnalliset kehityskulut. Lisäksi työläisillä on yhä enemmän omakohtaista tuntumaa teknisiin kysymyksiin oman työpaikan kokemuspiirissä: teknistä tietämystä ja taitoa. Vaikka se onkin teknisesti spesifiä tietoa ja taitoa, siihen kuitenkin sisältyy tekniselle ajattelulle ominaisten ajatusmuotojen tuntemus, jota puolestaan voidaan käyttää opetuksessa hyväksi lähdettäessä laajentamaan näkemystä tekniikan ja sen käytön yhteiskunnallisista ulottuvuuksista. Olemassa olevien tietojen ja kokemuksen pohjalta voi- 
daan ensin keskustelussa yrittää saada esiin osanottajien omia käsityksiä teknisistä ongelmista ja niiden yhteiskunnallisesta merkityksestä. Tekniikan kehityksestä voidaan sitten vetää konkreettisia yhteyksiä työttömyyteen, taloudellisiin suhteisiin tai yhteiskunnan voimavarojen suuntaamiseen eri alueille ja erilaisiin tarkoitusperiin jättämättä tällöin työläisten intressiperustaa ja välitöntä kokemuspiiriä kuitenkaan tyystin sivuun. Tekniikan ja luonnontieteen poliittisten ulottuvuuksien tavoin voidaan analysoida myös uusien teknisten sovellutusten aiheuttamia muutoksia työprosessissa, työn luonteen ja työn asettamien vaatimusten muuttumista tai siihen liittyviä fysiologisia tai psykologisia ongelmia. (Negt 1971, 114-117.)

\section{Lopuksi}

Harald Werner on kritisoinut Negtin eksemplaarisen oppimisen teoriaa teoriavihamieliseksi: se vastustaa oikeiden teoreettisten näkemysten ottamista ammattiyhdistyskoulutuksen lähtökohdaksi. (Werner 1979, 43.) Hän argumentoi sellaisen didaktisen mallin puolesta, joka lähtee teoreettisen aineksen opettamisesta ja etenee sen soveltamiseen konkreettisiin yhteyksiin (Werner 1982.).

Käsitteet on hänen mielestään opetettava ensin. Negtin esittämä menettely sen sijaan johdattaa vain ilmiöstä toiseen. (Werner 1975, 49.) Wernerin keskeinen ajatus näyttää olevan, että edistyksellisten tiedemiesten pitää tuoda työläisten tietoisuuteen kapitalismin lainalaisuudet (emt. 42.). Negt puolestaan katsoo epäonnistutun yrityksissä tunkea työläisille pää täyteen teoriakappaleita työstämättä heidän omia kokemuksiaan (Negt 1976, 377-8.).

Negtin keskeinen probleema on, miten välittää keskenään teoria ja kokemus. Kun eksemplaarisessa oppimisessa tällöin lähdetään liikkeelle arkikokemuksesta, tämä ei tarkoita, että tuo arkikokemus jätettäisiin alkuperäiseen tilaansa. Sitä on työstettävä, ja se edellyttää teoriaa - kollektiivisten kokemusten systematisointia, kategorioita ja käsitteitä, joiden avulla yhteiskunnan prosesseja ja konflikteja käsitetään. (Negt 1976, 376-7.)

Negt ei siis suinkaan halua kiistää teoreettisen tiedon tärkeyttä, päinvastoin se on välttämätöntä, mutta sitä ei voi kantaa sisään työläisten tietoisuuteen - kannettu vesi ei kaivossa pysy. Ongelma ei ratkea pohtimalla, kumpi on esitettävä ensin: yleinen vai yksittäinen, sil- lä kyse ei ole kahdesta peräkkäisestä, toisistaan erillään olevasta vaiheesta. Yleiset teoreettiset seikat hahmotellaan kokemusten (siis yksittäisen) erittelyn yhteydessä. Tämä yleinen teoreettinen aines ei luonnollisestikaan ole olemassa valmiina kokemuksessa, eikä kokemusten teoreettinen analyysi tapahdu itsestään. Jos näin olisi, jos luotettaisiin tyystin spontaaniin arkikokemukseen ja työläisten luovaan teoreettiseen voimaan, niin tällöinhän tietoinen koulutustyö olisi turhaa (Negt 1976, 377.). Vaikkei teoreettinen olekaan kokemuksessa olemassa, vaan on jotain siihen nähden uutta, niin sitä voidaan ja pitääkin käsitellä kokemusten erittelyn yhteydessä, jolloin se avautuu oppijalle paremmin tajuttavana ja nivoutuu hänen maailmaansa.

Wernerin tavoitteiden näkökulmasta hänen esittämänsä kritiikki kuitenkin osuu oikeaan: sinällään totena pidetyn ja sellaisena opetettavan teorian välittämisessä eksemplaarinen oppiminen ei ehkä ole tehokkain keino. Mutta Negtin pyrkimys onkin toinen: hän ei tavoittele valmiiden käsitysten opettamisen metodia, vaan keinoa opettaa ihmiset tulkitsemaan omaa tilannettaan yhteiskunnan rakenteellisten konfliktien valossa, opettaa heitä reaalisten tilanteiden teoreettiseen pohdintaan. Tältä kannalta katsoen Werner haukkuu väärää puuta vai lieneekö paremminkin väärä koira.

\section{Lähteet}

Mills, C. Wright: Sosiologinen mielikuvitus. Gaudeamus. Helsinki 1982.

Negt, Oskar: Soziologische Phantasie und exemplarisches Lernen. Zur Theorie der Arbeiterbildung. EVA. Frankfurt a.M. - Köln 1975. Erste Auflage 1971.

Negt, Oskar: Keine Demokratie ohne Sozialismus. Über Zusammenhang von Politik, Geschichte und Moral. Suhrkamp. Frankfurt a.M. 1976.

Negt, Oskar: Lebendige Arbeit, enteignete Zeit. Politische und kulturelle Dimensionen des Kampfes um die Arbeitszeit. Campus. Frankfurt a.M. 1984.

Werner, Harald: Das Prinzip des exemplarischen Lernens bei Oskar Negt oder die Folgen einer Theorie. Demokratische Erziehung $\mathrm{Nr}$ 4/1975.

Werner, Harald: Teoreettinen yleistäminen aykoulutuksessa. Aikuiskasvatus 2/1982.

Negt, Oskar: Haastattelu 1. Kauniainen lokakuu 1984. Haastattelijoina joukko toimittajia.

Negt, Oskar: Haastattelu 2. Helsinki lokakuu 1984. Haastattelijoina joukko sivistysjärjestöjen työntekijöitä. 